\title{
Bioequivalence Evaluation of Two Atenolol Tablet Preparations in Korean Healthy Male Volunteers
}

\author{
Hye Sun GwaK ${ }^{1}$ and In Koo ChUN* \\ College of Pharmacy, Dongduk Women's University, 23-1 Wolgok-Dong, Seongbuk-Gu, Seoul 136-714, Korea \\ ${ }^{1}$ College of Pharmacy, Ewha Womans University, 11-1 Daehyun-Dong, Seodaemun-Gu, Seoul 120-750, Korea
}

(Received 19 July 2007; Accepted 7 September 2007)

\begin{abstract}
This study was conducted to compare the bioavailability of two brands of atenolol (50 mg) tablets, which are a generic product of Ditent ${ }^{\circledR}$ (Daewon Pharmaceutical Co., Ltd., Korea) and an innovator product Tenormin $^{\circledR}$ (Hyundai Pharm. Ind. Co., Ltd., Korea), in 20 healthy Korean male volunteers. The volunteers received a single $50 \mathrm{mg}$ dose of each atenolol formulation according to a randomized, two-way cross-over design. The washout period between treatments was 1 week. Plasma samples were obtained over a 24-hour interval, and atenolol concentrations were determined by HPLC with a fluorescence detector. From the plasma atenolol concentration vs. time curves, the following parameters were compared: area under the plasma concentration-time curve $\left(\mathrm{AUC}_{0-24}\right)$, peak plasma concentration $\left(\mathrm{C}_{\text {max }}\right)$, time to reach peak plasma concentration $\left(\mathrm{T}_{\max }\right)$, and terminal first order elimination half-life $\left(\mathrm{t}_{1 / 2}\right)$. No statistically significant difference was obtained between the $\mathrm{T}_{\max }$ values, and the logarithmic transformed $\mathrm{AUC}_{0-24}$ and $\mathrm{C}_{\max }$ values of the two products. The $90 \%$ confidence interval for the ratio of the logarithmically transformed $\mathrm{AUC}$ and $\mathrm{C}_{\max }$ values of Ditent ${ }^{\circledR}$ over those of Tenormin ${ }^{\circledR}$ were calculated to be between 0.85 and 1.04 , and 0.89 and 1.07 , respectively; both were within the bioequivalence limit of $0.80-1.25$. The mean of $\mathrm{T}_{\max }$ in Tenormin ${ }^{\circledR}$ group was 3.1 hour, and that in Ditent ${ }^{\circledR}$ group was 3.2 hour. The values of $t_{1 / 2}$ between the two products were found comparable, and the mean values were 5.2 hour in the both products. Based on these results, it was concluded that Ditent ${ }^{\circledR}$ was comparable to Tenormin ${ }^{\circledR}$ in both the rate and extent of absorption, indicating that Ditent ${ }^{\circledR}$ was bioequivalent to the reference product, Tenormin ${ }^{\circledR}$.
\end{abstract}

Keywords $\square$ bioavailability, atenolol, bioequivalence

\section{INTRODUCTION}

Atenolol is a cardioselective beta- 1 adrenoreceptor blocker without intrinsic sympathomimetic and membrane-stabilizing activities (Harms, 1976; Hainsworth et al., 1973; Harry et al., 1973; Conway et al., 1976); it has been widely employed in the treatment of hypertension, angina pectoris, and cardiac arrythmias (Frishman, 1982; Heel et al., 1979).

Atenolol is a weak base whose $\mathrm{pK}_{\mathrm{a}}$ is 9.6 , with a partition coefficient of 0.015 between $n$-octanol/pH 7.4 phosphate buffer at $37^{\circ} \mathrm{C}$ (Heel et al., 1979). The bioavailability of atenolol is about $50 \%$ after oral administration. It is poorly bound to plasma proteins and only about $5 \%$ is metabolized by the liver. Due to its high hydrophilicity, atenolol is mainly eliminated unchanged by the kidneys (Stoschitzky et al., 1993).

*Corresponding author

Tel: +82-2-940-4523, Fax: +82-2-941-7652

E-mail: ikchun@dongduk.ac.kr
It is required to prove that the generic drug's extent and rate of absorption are not significantly different from those of the pioneer drug before the former can be safely used to replace the latter. In the present study, we compared the pharmacokinetic profiles of a generic product of atenolol, Ditent ${ }^{\circledR}$ with those of the original product, Tenormin ${ }^{\circledR}$ to examine that the generic is bioequivalent to the pioneer drug.

\section{MATERIALS AND METHODS}

\section{Materials}

Atenolol, metoprolol tartrate and sodium dodecyl sulfate (SDS) were purchased from Sigma Chemical Co. (St. Louis, MO, USA). Acetonitrile and methanol used were of HPLC grade. Other reagents were of analytical grade. Ditent ${ }^{\circledR}$ tablets (50mg; Lot No B018) were supplied by Daewon Pharmaceutical Co., Ltd. (Seoul, Korea). Tenormin ${ }^{\circledR}$ tablets (50mg; Hyundai Pharm. Ind. Co. Ltd., Korea Lot No. 11) were purchased from a local pharmacy. 


\section{Study design}

Twenty healthy male volunteers aged between 19 and 24 years (mean \pm S.D.: $20 \pm 1$ year), height between 166 and 195 $\mathrm{cm}(176 \pm 7 \mathrm{~cm})$ and weighing between 60 and $102 \mathrm{~kg}(75 \pm 10$ $\mathrm{kg}$ ) were selected for the study. All subjects gave written informed consent, and the clinical protocol was approved by the Ethics Committee of the University. The volunteers were judged to be healthy and were not receiving any medication during the study period.

The study was conducted in a single-dose, two-way crossover design. The volunteers were randomized, in a 1:1 ratio using a table of random numbers, into 2 groups; group A received a single dose of the generic formulation in period 1 and the branded formulation in period 2 while group $B$ received the branded formulation in period 1 and the generic formulation in period 2. The two treatment periods were separated by one-week washout period. Both products were administered with $240 \mathrm{ml}$ of water in the morning (8:30 A.M.) after 12-hr overnight fast. Food and drinks were withheld for at least $4 \mathrm{hr}$ after dosing. Lunch and dinner of beef soup with rice were served 4 and $10 \mathrm{hr}$ after dosing, and water was given ad libitum.

Seven milliliter of blood samples were collected in vacutainers (containing sodium heparin) via an in-dwelling cannula placed on the forearm before and 0.5, 1, 1.5, 2, 3, 4, 6, 8, 10, 12 and $24 \mathrm{hr}$ after the administration of each atenolol formulation. The blood samples were centrifuged at $3000 \mathrm{~g}$ for $15 \mathrm{~min}$ at room temperature, and the plasma was transferred to separate plasma tube. The separated plasmas were stored at $-70^{\circ} \mathrm{C}$ until analysis.

\section{Sample preparation and high performance liquid chro- matographic (HPLC) analysis}

\section{Preparation of standard solutions}

Working stock solutions of atenolol and metoprolol tartrate (internal standard, IS) were prepared in methanol at a concentration of $1 \mathrm{mg} / \mathrm{ml}$. Prior to use, these two stock solutions were further diluted with water to obtain working solutions.

\section{Sample preparation}

An appropriate dilution of the working solution with drug free plasma from healthy volunteers gave a concentration range between 20 and $500 \mathrm{ng} / \mathrm{ml}$ of atenolol. Plasma levels of atenolol were analyzed using a HPLC method reported by Winkler et al. (1982) with slight modification. To $1 \mathrm{ml}$ of plasma was added $100 \mu \mathrm{l}$ of IS $(20 \mu \mathrm{g} / \mathrm{ml})$ and $200 \mu \mathrm{l}$ of $0.5 \mathrm{~N}$ sodium hydroxide solution. After a brief vortex mixing, $7 \mathrm{ml}$ of a mix- ture of $n$-butanol and $n$-heptane $(1: 1, \mathrm{v} / \mathrm{v})$ was added and performed by vortex mixing for $3 \mathrm{~min}$. The tubes were then centrifuged at $3000 \mathrm{~g}$ for $5 \mathrm{~min}$, and the organic phase transferred to another set of clean tubes to be back-extracted with $200 \mu \mathrm{l}$ of $0.1 \mathrm{~N}$ hydrochloric acid (vortex mixing for $1 \mathrm{~min}$ ). The tubes were then centrifuged at $3000 \mathrm{~g}$ for $5 \mathrm{~min}$, and $50 \mu \mathrm{l}$ of the aqueous phase was injected into the liquid chromatograph.

\section{Chromatographic conditions}

The HPLC system consisted of a pump (SLC 100, Samsung, Korea) with a fluorescence detector (Shimadzu RF-535, Shimadzu, Japan) and an integrator (Varian Model-4290, Varian Incorp., USA). The reversed phase $\mathrm{C} 18$ column was eluted with a mixture of $0.02 \mathrm{M}$ phosphate buffer containing $0.1 \%$ SDS·methanol-acetonitrile (50:15:35, v/v) at a flow rate of $1.5 \mathrm{ml} / \mathrm{min}$. The fluorescence detector was set at 280 and 300 $\mathrm{nm}$ for excitation and emission, respectively. All analyses were performed at room temperature.

\section{Method validation}

\section{Specificity}

The degree of interference by endogenous plasma constituents with atenolol and IS was evaluated by inspection of chromatogram derived from processed blank and spiked plasma samples, and also from processed blank samples injected during each analytical run.

\section{Calibration curve}

Calibration standards at the concentrations of 20, 50, 100, 200, 300 and $500 \mathrm{ng} / \mathrm{ml}$ were extracted and assayed as mentioned above. The calibration curve was constructed based on peak area ratio of the drug and IS.

\section{Accuracy and precision}

Intra-day accuracy and precision of the method were estimated by assaying five replicate plasma samples at four different concentrations, in five analytical runs. The overall mean precision was defined by the percentage of relative standard deviation (RSD) of five standards at four different concentrations analyzed on the same day. Inter-day variability was estimated from the analysis of the five standards on five separate days during method validation.

\section{Extraction recovery}

Recovery of atenolol was determined by comparing 
observed atenolol peak area in extracted plasma, to those of non-processed standard solutions.

\section{Stability}

The freeze-thaw stability of atenolol in plasma was evaluated over three freeze-thaw cycles. Stability control plasma samples in triplicate at the levels of 100 and $500 \mathrm{ng} / \mathrm{ml}$ were immediately frozen at $-70^{\circ} \mathrm{C}$, and thawed at room temperature three consecutive times. After that, the samples were processed and assayed. The stability of atenolol in quality control samples stored at room temperature for $24 \mathrm{hr}$ and at $-70^{\circ} \mathrm{C}$ for 4 weeks was also assessed. The mean values of atenolol were compared with the initial ones, which were assayed immediately after preparation of stability control plasma samples. The stability was expressed as a percentage of the initial value.

\section{Pharmacokinetic and statistical analysis}

The first-order terminal elimination rate constant $\left(\mathrm{k}_{\mathrm{e}}\right)$ was estimated by linear regression from the points describing the elimination phase on a log-linear plot. Half-life $\left(t_{1 / 2}\right)$ was derived from the rate constant $\left(\mathrm{t}_{1 / 2}=\ln (2) / \mathrm{k}_{\mathrm{e}}\right)$. The maximum observed plasma concentration $\left(\mathrm{C}_{\max }\right)$ and the time taken to achieve this concentration $\left(\mathrm{T}_{\max }\right)$ were obtained directly from the curves. $\mathrm{AUC}_{0-24}$ was calculated using the trapezoidal formula.

Bioequivalence between both formulations was assessed by calculating individual $\mathrm{C}_{\max }, \mathrm{AUC}_{0-24}$ and $\mathrm{T}_{\max }$ differences (testreference) together with their mean and $90 \%$ confidence intervals (CI). The inclusion of the $90 \% \mathrm{CI}$ for the ratios into the 80 $125 \%$ range, and that of the zero value into the $90 \% \mathrm{CI}$ for the differences were analyzed by using an analysis of variance (ANOVA) procedure. The $\mathrm{AUC}_{0-24}$ and $\mathrm{C}_{\max }$ values were logarithmically transformed prior to the statistical analysis. The pharmacokinetic parameter calculation and bioequivalence assessment were conducted using BA Calc 2002 and K-BE Test 2002, respectively.

\section{RESULTS AND DISCUSSION}

Fig. 1 shows the well-resolved chromatographic peaks of atenolol and metoprolol at $3.2 \mathrm{~min}$ of atenolol and $7.0 \mathrm{~min}$ of metoprolol. The blank plasma after extraction consistently contains no significant interfering peaks.

The relation between atenolol concentrations and peak area ratio of atenolol to IS was linear from 20 to $500 \mathrm{ng} / \mathrm{ml}$ (y = $\left.0.0012 \mathrm{x}-0.0005, \mathrm{r}^{2}=0.9999\right)$.

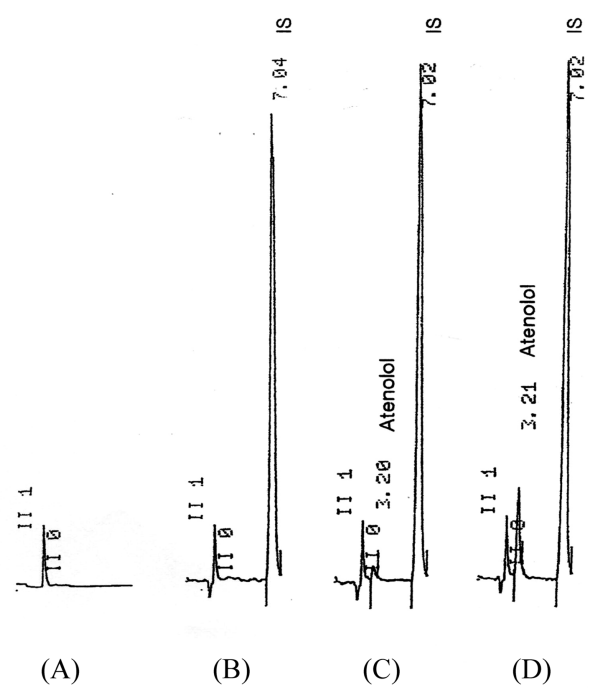

Fig. 1. Chromatograms for control human plasma (A), control plasma spiked with internal standard (IS, metoprolol tartrate 2 $\mu \mathrm{g} / \mathrm{ml})(B)$, control plasma spiked with atenolol $(20 \mathrm{ng} / \mathrm{ml})$ and IS (C) and control plasma spiked with atenolol (100 ng/ml) and IS (D).

Compared to the method by Winkler et al. (1982), this method could reduce the extraction time from $15 \mathrm{~min}$ to $3 \mathrm{~min}$ after addition of $n$-butanol $n$-heptane mixture $(50: 50, \mathrm{v} / \mathrm{v})$ without any peak area decrease. Also, we employed a lot of acids as a back-extraction fluid. Among them, $0.1 \mathrm{~N}$ hydrochloric acid revealed the highest extraction rate compared sulfuric acid, phosphoric acid or acetic acid with very brief back-extraction time (1 $\mathrm{min})$.

The limit of quantitation (LOQ) of atenolol was determined as the sample concentration of atenolol resulting in peak heights of 5 times $S_{\mathrm{N}}$. The LOQ was found to be $20 \mathrm{ng} / \mathrm{ml}$. The intra- and inter-day precisions of the methods were determined by the assay of five samples of drug-free plasma containing known concentrations of atenolol. As described in Table I, the intra- and inter-day RSD (\%) were within $15 \%$, which were acceptable for all quality control samples including the LOQ. The accuracy of atenolol ranged between 93.0 and $96.1 \%$. All the batches met the quality control acceptance criteria (Kamas et al., 1991).

The extraction recovery of atenolol at concentrations of 100 , 300 and $500 \mathrm{ng} / \mathrm{ml}$ was $99.7 \pm 0.5,98.2 \pm 0.6$ and $95.4 \pm 2.3 \%$ $(\mathrm{n}=3)$, respectively, while for IS at concentration of $2 \mu \mathrm{g} / \mathrm{ml}$ it was $100.1 \pm 1.2 \%(\mathrm{n}=3)$. These results suggested that there was no difference in extraction recovery at different concentrations of atenolol.

Knowledge of the stability of the drug in test material is a 
Table I. Intra- and inter-day precision and accuracy of atenolol assay for plasma

\begin{tabular}{cccc}
\hline \multirow{2}{*}{$\begin{array}{c}\text { Concentration } \\
(\mathrm{ng} / \mathrm{ml})\end{array}$} & \multicolumn{2}{c}{ Precision (RSD., \%) } & Accuracy (\%) \\
\cline { 2 - 3 }$(\mathrm{n}=5)$ & Intra $(\mathrm{n}=5)$ & Inter $(\mathrm{n}=5)$ & 96.1 \\
\hline 20 & 14.1 & 13.3 & 93.0 \\
100 & 10.1 & 4.5 & 93.1 \\
300 & 3.5 & 4.4 & 95.1 \\
500 & 2.3 & 1.5 & \\
\hline
\end{tabular}

Table II. Stability of atenolol in plasma

\begin{tabular}{ccc}
\hline $\begin{array}{c}\text { Concentration } \\
(\mathrm{ng} / \mathrm{ml})\end{array}$ & Treatment & $\begin{array}{c}\text { Percentage of } \\
\text { initial value }\end{array}$ \\
\hline \multirow{3}{*}{100} & Three freeze-thaw cycles & $98.2 \pm 4.7$ \\
& Stored at room temperature for $24 \mathrm{~h}$ & $96.1 \pm 3.3$ \\
& Stored at $-70^{\circ} \mathrm{C}$ for 4 weeks & $101.5 \pm 2.5$ \\
\hline \multirow{3}{*}{500} & Three freeze-thaw cycles & $97.2 \pm 3.1$ \\
& Stored at room temperature for $24 \mathrm{~h}$ & $95.6 \pm 4.8$ \\
& Stored at $-70^{\circ} \mathrm{C}$ for 4 weeks & $99.3 \pm 2.8$ \\
\hline
\end{tabular}

prerequisite for obtaining valuable data. The stability of atenolol under various conditions is described in Table II. Under all conditions tested, atenolol was stable with detected concentrations of at least $95.6 \%$ of the initial concentration.

Fig. 2 shows the mean plasma atenolol concentration-time profiles of Tenormin ${ }^{\circledR}$ and Ditent ${ }^{\circledR}$ tablets. The two profiles

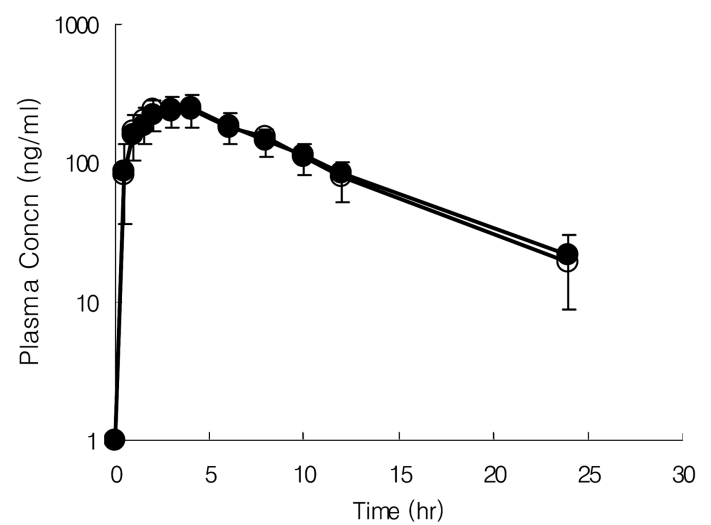

Fig. 2. Curves of mean plasma atenolol concentration vs time of Tenormin ${ }^{\circledR}(\bigcirc)$ and Ditent ${ }^{\circledR}(\bigcirc)$ tablets (mean \pm S.D., $n=20$ ).

were quite comparable. Peak plasma concentrations in both products were achieved at about $3 \mathrm{hr}$ after dosing.

Considering that the extent of absorption is a key characteristic of a drug formulation, AUC is an important parameter for comparative bioavailability study. $\mathrm{C}_{\max }$ is another critical parameter because it is related to the rate and extent of absorption (Endrenyi et al., 1991). Even though $\mathrm{T}_{\max }$ is not usually included in the bioequivalence study, it is also important feature

Table III. Pharmacokinetic parameters for each volunteer obtained after oral administration of Tenormin ${ }^{\circledR}$ and Ditent ${ }^{\circledR}$ tablets at the atenolol dose of $50 \mathrm{mg}$

\begin{tabular}{|c|c|c|c|c|c|c|c|c|}
\hline \multirow[b]{2}{*}{ Subjects } & \multicolumn{4}{|c|}{ Tenormin $^{\circledR}$ Tablets } & \multicolumn{4}{|c|}{ Ditent $^{\mathbb{R}}$ Tablets } \\
\hline & $\mathrm{T}_{\max }(\mathrm{hr})$ & $\mathrm{C}_{\max }(\mathrm{ng} / \mathrm{ml})$ & $\operatorname{AUC}_{0-24}(\mathrm{ng} \cdot \mathrm{hr} / \mathrm{ml})$ & $\mathrm{t}_{1 / 2}(\mathrm{hr})$ & $\mathrm{T}_{\max }(\mathrm{hr})$ & $\mathrm{C}_{\max }(\mathrm{ng} / \mathrm{ml})$ & $\mathrm{AUC}_{0-24}(\mathrm{ng} \cdot \mathrm{hr} / \mathrm{ml})$ & $\mathrm{t}_{1 / 2}(\mathrm{hr})$ \\
\hline A-1 & 4 & 292.0 & 2889.6 & 6.3 & 2 & 315.9 & 2977.3 & 6.5 \\
\hline A-2 & 3 & 262.2 & 3099.7 & 3.6 & 4 & 287.2 & 2948.4 & 6.1 \\
\hline A-3 & 4 & 240.4 & 2283.9 & 4.6 & 3 & 208.9 & 2031.4 & 5.5 \\
\hline A-4 & 2 & 237.3 & 2894.7 & 4.4 & 4 & 301.4 & 3149.7 & 6.9 \\
\hline A-5 & 2 & 305.5 & 3954.0 & 3.6 & 4 & 360.7 & 2468.1 & 4.4 \\
\hline A-6 & 4 & 185.8 & 1769.9 & 8.2 & 4 & 140.7 & 1644.2 & 7.6 \\
\hline A-7 & 4 & 316.2 & 2778.9 & 4.9 & 4 & 321.9 & 2823.4 & 5.1 \\
\hline A- 8 & 2 & 268.2 & 3460.5 & 3.8 & 3 & 154.5 & 1607.2 & 6.0 \\
\hline A-9 & 4 & 211.7 & 2041.2 & 3.6 & 3 & 228.5 & 1977.2 & 6.2 \\
\hline A-10 & 2 & 281.1 & 3015.5 & 3.8 & 3 & 280.6 & 1802.0 & 4.8 \\
\hline B-1 & 4 & 328.4 & 2751.9 & 4.7 & 3 & 272.9 & 2578.7 & 5.1 \\
\hline B-2 & 3 & 293.6 & 2865.2 & 5.8 & 4 & 311.5 & 2166.5 & 5.3 \\
\hline B-3 & 2 & 375.8 & 2786.1 & 6.3 & 2 & 352.1 & 2946.2 & 4.4 \\
\hline B-4 & 3 & 246.9 & 2188.1 & 5.5 & 2 & 241.0 & 1421.4 & 4.1 \\
\hline B-5 & 2 & 238.2 & 2057.3 & 5.9 & 2 & 286.3 & 2321.5 & 4.2 \\
\hline B-6 & 4 & 319.0 & 2904.6 & 6.4 & 2 & 265.7 & 2392.0 & 3.7 \\
\hline B-7 & 2 & 233.0 & 2038.8 & 8.1 & 2 & 390.4 & 2795.3 & 4.6 \\
\hline B-8 & 3 & 394.0 & 3359.9 & 3.6 & 2 & 315.3 & 2654.7 & 4.8 \\
\hline B-9 & 6 & 273.1 & 2651.5 & 5.4 & 6 & 251.5 & 2410.5 & 3.7 \\
\hline B-10 & 3 & 273.9 & 2611.8 & 5.5 & 4 & 235.4 & 2452.9 & 4.9 \\
\hline Mean & 3.1 & 278.8 & 2507.3 & 5.2 & 3.2 & 276.1 & 2378.4 & 5.2 \\
\hline SD & 1.1 & 51.7 & 404.8 & 1.4 & 1.1 & 63.6 & 503.4 & 1.1 \\
\hline
\end{tabular}


Table IV. Analysis of variance of pharmacokinetic parameters (logarithm-transformed) of generic versus branded atenolol 50-mg tablet in 20 Korean healthy male volunteers

\begin{tabular}{cccc}
\hline $\begin{array}{c}\text { Source of } \\
\text { variation }\end{array}$ & $\begin{array}{c}\text { Pharmacokinetic } \\
\text { parameters }\end{array}$ & F value & F table \\
\hline Sequence & $\mathrm{C}_{\max }$ & 2.780 & 4.414 \\
& $\mathrm{AUC}_{0-24}$ & 0.938 & 4.414 \\
Subject & $\mathrm{C}_{\max }$ & 2.136 & 2.217 \\
& $\mathrm{AUC}_{0-24}$ & 1.488 & 2.217 \\
Period & $\mathrm{C}_{\max }$ & 0.021 & 4.414 \\
& $\mathrm{AUC}_{0-24}$ & 0.172 & 4.414 \\
Drug & $\mathrm{C}_{\max }$ & 0.198 & 4.414 \\
& $\mathrm{AUC}_{0-24}$ & 1.250 & 4.414 \\
\hline
\end{tabular}

of the plasma level profile that is related to absorption and elimination rate (Shargel and $\mathrm{Yu}, 1999$ ). Individual values of $\mathrm{T}_{\max }$, $\mathrm{C}_{\max }$ and $\mathrm{AUC}_{0-\infty}$ are listed in Table III. No statistical difference found between the mean $\mathrm{T}_{\max }$ values of Tenormin ${ }^{\circledR}$ and Ditent ${ }^{\circledR}$ tablets $(p=1)$. Also, no statistically significant difference was obtained between the logarithmic transformed $\mathrm{C}_{\max }$ values $(\mathrm{p}=0.6525)$, as well as the logarithmically transformed $\mathrm{AUC}_{0-24}(\mathrm{p}=0.3262)$ of the two products.

The results from the ANOVA in Table IV indicated that sequence, subject, period and drug had no statistically significant effect on $\mathrm{C}_{\max }$ and $\mathrm{AUC}_{0-24}$ at the significance level of 0.05 . In addition, the $90 \%$ CI for the ratio of the logarithmically transformed $\mathrm{AUC}_{0-24}$ values of Ditent ${ }^{\circledR}$ over those of Tenormin ${ }^{\circledR}$ was found to be between 0.85 and 1.04, while that of the logarithmically transformed $\mathrm{C}_{\max }$ values was between 0.89 and 1.07 , both being within the acceptable bioequivalence limit of 0.80 1.25. The $\mathrm{t}_{1 / 2}$ values ranged between 3.6 and $8.2 \mathrm{hr}$, with a mean value of approximately $5.2 \mathrm{hr}$ in both product and were not significantly statistically different $(\mathrm{p}=0.9873)$. This value is in accordance with that reported by other studies using other race groups (Fitzgerald et al., 1978; Martins et al., 1997).

\section{CONCLUSIONS}

On the basis of these results, it can be concluded that Ditent ${ }^{\circledR}$ and Tenormin ${ }^{\circledR}$ are comparable in both the rate and extent of absorption, indicating that Ditent ${ }^{\circledR}$ is bioequivalent to Ten$\operatorname{ormin}^{\circledR}$.

\section{REFERENCES}

Conway, F. J., Fitzgerald, J. D., McAinsh, J., Rowlands,
D. J. and Simpson, W. J. (1976). Human pharmacokinetic and pharmacodynamic studies on the atenolo (ICI 66, 082), a new cardioselective beta-adrenoceptor blocking drug. Br. J. Clin. Pharmacol. 3, 267-272.

Endrenyi, L., Fritsch, S. and Yan, W. (1991). $\mathrm{C}_{\max } / \mathrm{AUC}$ is a clear measure than $\mathrm{C}_{\max }$ for absorption rates in investigations of bioequivalence. Int. J. Clin. Pharmacol. 29, 394-399.

Fitzgerald, J. D., Ruffin, R., Smedstad, K. G., Roberts, R. and McAinsh, J. (1978). Studies on the pharmacokinetics and pharmacodynamics of atenolol in man. Eur. J. Clin. Pharmacol. 13, 81-89.

Frishman, W. H. (1982). Atenolol and timolol, two new systemic $\beta$-adrenoceptor antagonists. N. Engl. J. Med. 306, 1424-1462.

Hainsworth, R., Karim, F., Stoker, J. B. and Harry, J. D. (1973). The blocking effects of propranolol, practolol and ICI-66082 on the peripheral vascular responses to isoprenaline. Brit. J. Pharmacol. 48, 342-343.

Harms, H. H. (1976). Isoproterenol antagonism of cardioselec-tive beta adrenergic receptor blocking agents: a compara-tive study of human and guinea-pig cardiac and bronchial beta adrenergic receptors. J. Pharmacol. Exp. Ther. 199, 329-335.

Harry, J. D., Knapp, M. F. and Linden, R. J. (1973). The action of ICI-66082 on the heart. Brit. J. Pharmacol. 48, 340-341.

Heel, R. C., Brogden, R. N., Speight, T. M. and Avery, G. S. (1979). Atenolol: a review of its pharmacological properties and therapeutic efficacy in angina pectoris and hypertension. Drugs 17, 425-460.

Kamas, H. T., Shiu, G and Shah, V. P. (1991). Validation of bioanalytical methods. Pharm. Res. 8, 421-426.

Martins, M. L., Pierossi, M. A., Moraes, L. A., Ribeiro, W., Abbib Jr., W., Mendes, G B., Poli, A., De Nucci, G and Muscara, M. N. (1997). Comparative bioavailability of two atenolol tablet formulations in healthy male volunteers after a single dose administration. Int. J. Clin. Pharmacol. Ther. 35, 324-328.

Stoschitzky, K., Egginger, G., Zernig, G., Klein, W. and Lindner, W. (1993). Stereoselective features of (R)- and (S)-atenolol: clinical pharmacological, pharmacokinetic and radioligand binding studies. Chirality 5, 15-19.

Winkler, H., Ried, W. and Lemmer, B. (1982). Highperformance liquid chromatographic method for the quantitative analysis of the aryloxypropanolamines propranolol, metoprolol and atenolol in plasma and tissue. J. Chromatogr. 228, 223-234.

Shargel L. and Yu, A. (1999). Applied Biopharmaceutics and Pharmacokinetics. Prentice Hall International, London. pp. 223-245. 